\title{
Public Policy Analysis by The Government of Pati on Negative Impact of Prevention of Karaoke for The Tourism Businesses
}

\author{
Sema Ardianto ${ }^{1}$ and Widayati ${ }^{2}$
}

Abstract. Pati Regency is a potential area in terms of tourism development, in addition to a relatively wide area is also crossed by lanes north coast. So often tourists from other regions that could pass stopover to rest and enjoy the tourism facilities in Pati. one tourism in Pati are tourism enterprises of karaoke. Karaoke tourism businesses experience rapid growth in every year. However, the tourism business is growing very rapidly karaoke if not offset by a provision concerning how the karaoke business is operational in accordance with properly, causing this karaoke tourism business potential for misuse to be a place of prostitution. Circumstances such as this would require local governments to adopt policies in addressing the phenomenon of tourism in the district of Pati. Especially tourism type of karaoke, karaoke business for the existence not adversely affect the community in the district of Pati. This research used socio-juridical approach. Data were obtained by means of field research, then the data is analyzed by qualitative descriptive analysis. The results showed that the measures taken by the District Government Pati experiencing constraints in its implementation in society.

Keywords : Analysis, Public Policy, Tourism, Karaoke.

\section{Introduction}

Policy is an instrument of government, not only in the sense that only the Government concerning the State apparatus, but also touching management governance of public resources. Policies are essentially decisions or choices of action that directly regulate pengelolahan and distribution of natural resources, financial and human beings for the sake of public interest. ${ }^{3}$

Public policies are directly or indirectly has been known in the community, along with a wide range of phenomena and activities going on in the government. Likewise the phenomenon in business activities there must be policies that govern them. Given that the world of business experienced a very tough competition including karaoke business are offset by the development of tools that is increasingly sophisticated technology making it easier for any company to improve its business performance in order to achieve the goal, namely to profit as much as possible with a minimum of sacrifice.

In the social life of human needs is divided into three: the need for primary, secondary, and tertiary. The primary requirement is a basic requirement that consist on food, education, etc. Secondary needs consist of tourism, recreation, and entertainment. The tendency of the growing importance of the need for entertainment is basically reasonable and humane, namely to maintain physical and mental balance so it can be fresh the next day. The impact of these changes in lifestyle, encourage emergence and development of the entertainment business so that from day to day, the presence of entertainment venues flourishing large and small urban environment.

The rise of karaoke entertainment world that has been unstoppable again also adds to the

\footnotetext{
${ }^{1}$ Student of Masters (S2) of Law Faculty of Law Unissula Semarang e-mail semaardianto@gmail.com

${ }^{2}$ Lecturer of Faculty of Law UNISSULA Semarang

${ }^{3}$ Edi Suharto 2008 Kebijakan Sosial Sebagai Kebijakan Publik CV Alfabeta Bandung p. 3.
} 
frenetic atmosphere of the city and has now spread out to a small town like at Pati. The phenomenon that occurs in Pati, namely the existence of places of entertainment karaoke disturbing the community because the community views to be bad and negative, it is also triggered by the presence of karaoke that is a very flourishing and less structured primarily along the road north coast are much traversed by many visitors who are just passing or on vacation Pati, of this phenomenon makes the public's view starch getting worse but these icons can be pushed, turned out in other cities also have the same phenomenon, grow and karaoke entertainment like mushrooms in the rainy season.

If seen from the region in Pati Regency traversed northern coastal road has the potential for the development of business which has been especially rapid development of tourism businesses karaoke requires governments to create policies that govern them, not only in positive terms set out in the policy, for example on local revenues generated from taxes karaoke business, but also because of the negative of the karaoke business that can damage morale and life structure in society.

Tourism business has potential negative impact on the wider community is karaoke tourism enterprises, although efforts are basically karaoke tourism businesses provide places and facilities sing with or without a guide track, but in fact it is common knowledge as well as entertainment venues sing well in practice misused as a sale of liquor, drug abuse and prostitution.

For that it is necessary Pati regency government established a policy that really appropriate to be able to regulate and curb the karaoke business so that the tourism industry can be beneficial as it should karaoke without making restless and have a negative impact for the wider community.

\section{Research Methods}

This type of research used in this research is a field research, which this study focuses on the results of data collection from respondents who have been determined. The type of research is that researchers do research qualitative descriptive method.

The type and source of the data contained in this study were: 1) Primary data, ie data obtained directly from observation by interview or interviews, namely data collection techniques by asking questions directly to the respondent; 2) The secondary data, ie data obtained by the study of literature. Secondary Data include Law, books, magazines, newspapers etc.

Data collection techniques performed by: 1) Observation, namely direct observation to study sites to see how Pati Regency Government in tackling the negative impact of tourism businesses Karaoke by Act No. 8 of 2013 on the Implementation of Tourism in Pati regency; 2) interview, the authors conducted a question and answer directly to the respondents in order to obtain data on the problem to be studied; 3) Documentation, a study conducted by collecting data and collect documents either written documents, images, and electronic media in determining the policy of implementation of Act No. 8 of 2013 on the Implementation of Tourism in Pati regency.

Researchers using qualitative descriptive methods in the analysis of data that describes the theory with the objective conditions encountered in the field. This is done by steps and certain stages. The steps it is to collect the necessary data, then classified according to the type and specifications. Subsequently analyzed qualitatively with the description and explanation of the support. After that the conclusions drawn from the analysis that the 
final results of the study.

\section{Result and Discussion}

Before researchers discuss on core policy issues to prevent the negative impact of the karaoke business needs be explained first about some understanding and opinions of experts on the policy. There are many opinions expressed by experts with diverse definitions. Public policy according to Thomas R. Dye defined as "Whatever Governments chooses to do or not to do". Public policy is what governments choose to do or not do something. ${ }^{4}$ Meanwhile James Anderson "Public Policy is a policy developed by the agency and government officials". ${ }^{5}$ This understanding shows bahwasannya government has the authority to make choices about which policies will be carried out or not, depending on the problems that arise or outcomes you want to jump from the policies made.

In essence, public policy made by the government in the form of government actions. Public policy, either to do or not do something has a specific purpose. Public policy is for the benefit of society.

Public policy is usually contained in legislation such as the legislation (the Act), a presidential decree, and local regulations are forms of public policy. Public policy or public policy of the programs implemented by the government in its broadest sense to achieve community goals. In other words, public policy decisions is an authorized institution or government who represent the public interest. ${ }^{6}$ Such as policies on basic electricity tariff (TDL), phone rates, fuel prices, and the city bus fare as well as increasing the role of the library.

Manufacture government policies are always preceded by a variety of things and the underlying background as the reason for the adoption of the policy. as we all know that a policy can be a law, regional regulation, decree and so forth. Hence the phenomenon of society in Pati regency which has flourished with many tourism businesses that have been operating so long before the establishment of Regulation No. 8 of 2013 on the Implementation of Kepariwsataan, this led to wild tourism businesses in Pati regency in the absence of regulations governing the tourism business, so that in operation without control and without the supervision of the Local Government which result in practice is often deviations in the tourism business, especially the tourism industry karaoke. Of the problems that wild tourism business without the control of the government in society in Pati regency makes religious social organizations in Pati regency furious and perform largescale demonstrations in 2010 ago. Of the various phenomena and these problems require the government must immediately took measures to address the existing problems. With the establishment of Pati Regency Regulation No. 8 of 2013 on the Implementation of Tourism will be able to solve problems and be a response to the demands and pressure from society.

Formation of Regional Regulation on the Implementation of Tourism is a form of local government in an effort to curb the tourism industry especially crucial is the effort of

\footnotetext{
${ }^{4}$ Thomas R. Dye 1987 Understanding Public Policy Engelewood Chief New Jersey Prentince-Hall Inc p. 3. In Esmi Warassih 2016 Pranata Hukum Sebuah Telaah Sosiologis Pustaka Magister Semarang p. 101.

${ }^{5}$ Sahya Anggara 2014 Kebijakan Publik CV Pustaka Setia Bandung p. 35.

${ }^{6}$ Surya Dailiti Hernimawati dan Sudaryanto "Agenda Kebijakan Publik pada badan perpustakaan dan arsip (BPA) Kota Pekanbaru” Jurnal Niara Vol. 10 No. 1 Juli 2017 Universitas Lancang Kuning p. 2.
} 
karaoke in Pati regency, with the establishment of regional regulation on the operation of tourism is expected to become the basis for management of tourism in the region, especially to restructure and curb karaoke business that has long operated without control. Tourism Operation purpose of the establishment legislation is due to social problems that are considered by people disrupt public order and damaging public morals in Pati regency.

The underlying reasons for local governments with policies made in the form of Pati Regency Regulation No. 8 of 2013 were as follows:

- The absence of regulations governing tourism.

- The existence of crucial issues about tourism businesses karaoke considered an adverse impact on people's lives.

- The public demands to the district government to curb tourism businesses starch karaoke.

- Under the mandate of the Tourism Act No. 10 of 2009.

In the terms and conditions of Regulation district. Starch No. 8 Of 2013 on the Implementation of Tourism is already regulated in detail about the tourism business is no exception with tourism businesses karaoke from within a tourist location karaoke mention that the location types of tourism businesses karaoke is at least 1,000 (one thousand) meters daeri places of worship, schools, residential, offices and / or hospital. (Vide Article 25 paragraph (1) Regulation district. Pati No. 8/2013). The purpose of this provision is that the tourism industry can be minimized karaoke from frequent contact with the public in order to reduce the resulting negative impact.

As for the location karaoke tourism businesses that still exist in the area of Pati regency is as follows:

Table 1. The location and amount of Karaoke in Pati regency.

\begin{tabular}{|c|l|c|}
\hline No & District name & Number of karaoke \\
\hline 1 & Pati & 13 \\
\hline 2 & Tayu & 1 \\
\hline 3 & Juwana & 5 \\
\hline 4 & Gabus & 2 \\
\hline 5 & Margorejo & 13 \\
\hline \multicolumn{2}{|c|}{ amount } & 34 \\
\hline
\end{tabular}

(Source: municipal police Pati Regency, 2018)

Of the 21 districts in Pati regency the District Pati, Wedarijaksa, Trangkil, Margoyoso, Tayu, Dukuhseti, Cluwak, Gunungwungkal, Juwana, Jaken, Jakenan, Batangan, Pucakwangi, Gabus, Winong, Kayen, Sukolilo, Tambakromo, Gembong, Tlogowungu, Margorejo, based on the table above are only five (5) districts which are tourism enterprises karaoke, and the five sub-districts is a location that is very much the settlement and its inhabitants, and therefore of course the tourism industry this karaoke if operating in these areas means that they break the provisions of the Regulation on the Implementation of Tourism which regulates the distance of 1,000 meters from the settlement etc.

In the karaoke business operations as defined in Regulation 8/2013 Pati location other than specified distances are also given the rights, obligations and restrictions for tourism businesses of karaoke. Rights and obligations in the karaoke business, among other things: 
- Providing karaoke room or hall, soundproofed, made of clear glass and translucent (transparent), must not be locked during the operation, lights were white and not turned off. (Vide Article 27 paragraph (1) letter as / ss)

- If the provided guides karaoke (PK), then the guide should dress modestly karaoke accordance with religious norms. (Vide Article 28 paragraph (2) and (3) d).

Other than the rights and obligations, there are also restrictions for karaoke businesses, namely:

- Must not create enclosed spaces indoors karaoke (vide Article 27 paragraph (1) letter e)

- Prohibited make glass chamber to the rest room karaoke guide

- Prohibited from displaying photographs karaoke guide (vide Article 27 paragraph (2))

Non-operational karaoke businesses on religious holidays including Ramadhan. (Vide Article 29 paragraph (2) and (3) b)

Of the various terms and conditions mentioned above are expected to minimize the negative impacts and karaoke abuse tourism businesses in the District of Pati. But in reality the policy implementation of Regulation No. 8 Of 2013 concerning the Implementation of Tourism is not as easy as turning the palm of the hand, in other words a lot happening in the implementation constraints in implementation. The constraints are:

- Many entrepreneurs karaoke which do not comply with the provisions of Regulation on tourism penyelenggaraaan because they feel that their karaoke business existed long before the existence of the regulation.

- Public awareness to obey is still very low, especially those who like the karaoke entertainment activities and businesses that benefit from the karaoke business, such as a motorcycle taxi driver and cafes are located close to the karaoke business.

- Opposing and obstructing the municipal police members who were acting to curb in order to seal karaoke legal effort to mobilize the masses by way of a group of thugs.

- The lack of deterrent effect set out in legislation, ranging from administrative sanctions to criminal sanction.

- The lack of municipal police personnel in Pati regency not even a little old, so it is less able to curb forced to tourism businesses karaoke.

- Municipal police force investigator in only 1 (one) person, so as to do less than the maximum judicial action.

- Differences in perception with other agencies, especially with the Police in Pati regency.

Of the various problems on top of it all causes Pati Regency Government efforts in order to enforce and implement Pati Regency Regulation No. 8 of 2013 to be obstructed by it. Despite that the local government will continue to make efforts towards surveillance and control efforts karaoke until the effort was really in accordance with the provisions and operational as intended.

Some of the things that become an obstacle in the implementation of Act No. 8 of 2013 on the Implementation of the tourism one of which is due to economic factors which can be a support revenues for the needs of local community life, namely by businesses cafe, motorcycle taxi drivers and especially for businesses karaoke itself, though in one side of their businesses karaoke can be said to be a supporter of life and economy of the community in the surrounding area, but on the other hand the impact caused by businesses karaoke incredible bad to the general public who make moral deterioration of society tersebab by the efforts of karaoke that was allegedly the scene of prostitution and 
sale liquor the karaoke business is as it should be done closure or with the setting,control and enforcement in doing karaoke business.

According to the author's opinion rejecting any attempt karaoke ravages that cause damage to the moral and social order comprehensive in Pati regency takes precedence (shutting karaoke) rather than having to pull benefit form of increased welfare of the people around by letting the karaoke business continues to operate.

\section{Closing}

\subsection{Conclution}

Policy decisions such as the establishment of Regional Regulation No. 8 of 2013 on the Implementation of Tourism is a proper action by the local government district of Pati though implementation is not yet fully implemented but the efforts of the regional government still continue until the objectives of the policy actually has been done as it should be.

Although the implementation of the policy does not go easy but a bit much with the Regulation No. 8 in 2013 have made changes and reduce the negative impact caused by tourism businesses karaoke. Therefore the aim of the policy in the form of the Implementation Regulation of Tourism for reorganize businesses karaoke tourism can be said to provide good results for the people in the district of Pati.

\subsection{Suggestion}

Policy is the government's way to organize society to act properly in a common life, so when a policy by the government is opposed by the public in part while the majority of others support, based on this problem, rejecting ugliness takes precedence over seeking the good, therefore the policy must be established, so that the objectives of these policies can be realized as it should be.

\section{References}

[1] Edi Suharto 2008 Kebijakan Sosial Sebagai Kebijakan Publik CV Alfabeta Bandung.

[2] Esmi Warassih 2016 Pranata Hukum Sebuah Telaah Sosiologis Pustaka Magister Semarang.

[3] Sahya Anggara 2014 Kebijakan Publik CV Pustaka Setia Bandung.

[4] Surya Dailiti Hernimawati dan Sudaryanto "Agenda Kebijakan Publik pada badan perpustakaan dan arsip (BPA) Kota Pekanbaru" Jurnal Niara Vol. 10 No. 1 Juli 2017 Universitas Lancang Kuning.

[5] Thomas R. Dye 1987 Understanding Public Policy Engelewood Chief New Jersey Prentince-Hall Inc.

[6] Act No. 10 of 2009 on Tourism

[7] Pati Regency Regulation No. 8 of 2013 on the Implementation of Tourism 